\title{
Erratum to: Optimum material design of minimum structural compliance under seepage constraint
}

\author{
Shengli Xu • Gengdong Cheng
}

Published online: 25 September 2010

(C) Springer-Verlag 2010

Erratum to: Struct Multidisc Optim

DOI 10.1007/s00158-009-0438-5

The original version of this article unfortunately contained a mistake. The corresponding author should have been Gengdong Cheng (chenggd@dlut.edu.cn).

The online version of the original article can be found at http://dx.doi.org/10.1007/s00158-009-0438-5.

S. Xu · G. Cheng ( $\square)$

Dalian University of Technology, Dalian,

People's Republic of China

e-mail: chenggd@dlut.edu.cn

S. Xu

e-mail: shengli.xu.xu@gmail.com 